\title{
PENERAPAN METODE FUZZY AHP DALAM MENENTUKAN PEMBELIAN MOBIL KELUARGA
}

\author{
Haerudin A. Koloid ${ }^{1}$, Wrastawa Ridwan ${ }^{2}$, Ifan Wiranto ${ }^{3}$ \\ ${ }^{123}$ Prodi Teknik Elektro Universitas Negeri Gorontalo \\ Email: haerudin_angk14@gmail.com; ifan_te@ung.ac.id,wridwan@ung.ac.id
}

\begin{abstract}
Abstrak
Penelitian ini bertujuan untuk menerapkan metode fuzzy analytical hierarchy process (F-AHP) dalam merancang sistem pendukung keputusan untuk membeli mobil keluarga. Pengumpulan data dilakukan dengan cara mencari informasi pada dealer mobil kota gorontalo tentang kriteria apa saja yang menjadi patokan pembeli. Hasil wawancara diperoleh bahwa kriteria memilih pembelian mobil keluarga yaitu harga, suku cadang, jumlah tempat duduk, irit bahan bakar, luas bagasi, body (eksterior) dan model (interior). Kriteria-kriteria tersebut diberi penilaian perbandingan berpasangan dengan AHP untuk menentukan konsistensi rasio dan menggunakan TFN untuk mencari upper excepted value.

Hasil yang didapat menunjukkan bahwa kriteria harga, suku cadang, jumlah tempat duduk, irit bahan bakar, luas bagasi, body (eksterior), dan model (interior) dengan nilai bobot yaitu harga 28,290 $\%$, suku cadang 10,388 \%, jumlah tempat duduk 22,862 \%, irit bahan bakar 29,144\%, luas bagasi $1,7340 \%$, body (eksterior) 5,5460 \%, model (interior) 1,7340 \%. Dapat disimpulkan bahwa kecenderungan masyarakat gorontalo dalam memilih mobil keluarga lebih mementingkan irit dengan nilai bobot $29,144 \%$.

Pada penelitian ini juga dibuatkan suatu aplikasi yang dapat membantu dan memudahkan pembeli dalam menentukan pembelian mobil keluarga.
\end{abstract}

Kata kunci:Fuzzy AHP, Mobil Keluarga

\section{PENDAHULUAN}

Mobil merupakan salah satu alat transportasi yang membantu manusia dalam menyediakan berbagai fasilitas dan kemudahan, seperti pelayanan untuk perorangan maupun kelompok untuk mempersingkat waktu yang ditujui.Seorang pembeli kendaraan mobil keluarga dalam menentukan pilihannya, tentu didasarkan pada beberapa kriteria yang dijadikan patokan dalam memilih kendaraan (mobil) keluarga antara lain harga, suku cadang, jumlah tempat duduk, irit, luas bagasi, body (eksterior) dan model (interior). Kriteria tersebut menjadi pertimbangan untuk membeli kendaraan mobil keluarga yang akan dibeli, teryata tidaklah mudah bagi pembeli yang belum memahami seluk beluk kendaraan mobil keluarga. Maka perlu suatu rujukan dalam memilih kendaraan mobil keluarga. Sistem pendukung keputusan yang ditawarkan menggunakan metode Fuzzy Analitical Hierarchy Proces (F-AHP).

Pembeli kendaraan mobil keluarga dapat memilih kendaraan mobil keluarga berdasarkan rujukan atau rekomendasi dari sistem pendukung 
keputusan yang dijalankan oleh admin.

Sistem tersebut dapat membantu calon pembeli dengan memberikan hasil alternatif pilihan kendaraan (mobil) keluarga yang diperoleh dari perhitungan Fuzzy Analitical Hierarchy Proces (F-AHP) berdasarkan hasil peritungan factor kriteria-kriteria penilaian yang diajukan kesistem maka penentuan kendaraan (mobil) keluarga bisa diperoleh melalui perhitungan nilai bobot prioritas untuk pemilian alternatif kendaraan (mobil) keluarga yang akan dibeli.

Adanya sistem pendukung keputusan untuk memilih kendaraan (mobil) keluarga dengan menggunakan metode Fuzzy Analitical Hierarchy Proces (FAHP) diharapkan dapat membantu calon pemebeli dalam pemilihan kendaraan (mobil) keluarga dan dapat menghasilkan suatu hasil yang optimal yang memenuhi rasa kepuasan yang tinggi bagi pembeli kendaraan (mobil) keluarga yang bertujuan untuk menentukan pilihan terbaik dari beberapa alternatif.

Beberapa penelitian tentang aplikasi Fuzzy AHP telah dilakukan, di antaranya Artika (2013) menggunakan F-AHP untuk menentukan kriteria kinerja guru, Arif dan Sunoto (2014) menggunakan F-AHP untuk seleksi penerimaan guru, Galus (2015) menggunakannya untuk perangkingan siswa, Adnyana dan Nilakusumawati menggunakan F-AHP untuk menentukan sektor wisata yang berpengaruh terhadap perekonomian Provinsi Bali, serta Wahyuni dan Hartati (2012) menggunakan metode FAHP untuk menentukan kualitas perdagangan batu mulia.

\section{METODE PENELITIAN}

Materi penelitian yang digunakan berupa data-data yang dikumpulkan dari Dealer Mobil Provinsi Kota Gorontalo. Data yang dimaksud, berupa data-data terkait dalam proses pembuatan sistem pendukung keputusan. Data-data yang diperoleh ini digunakan sebagai acuan kriteria untuk keperluan pembuatan kuesioner untuk sistem pendukung keputusan dalam menentukaan pembelian mobil keluarga.

Proses pengumpulan data dalam penyusunan laporan ini, menggunakan dua cara,yaitu :

Wawancara : Dilakukan untuk mendapatkan data kriteria mobil keluarga yang nantinya akan menjadi penilaian untuk mendapatkan nilai 
kriteria dalam menentukan mobil keluarga yang akan dibeli.

Survey Lapangan : dilakukan untuk mengambil data kriteria mobil keluarga yaitu dengan melakukan pembagian kuesinor kepada 100 orang responden yang menjadi data penelitan. Melakukan pengambilan data kriteria prioritas konsumen dalam menentukan pilihan mobil keluarga yang akan dibelinya. Data kriteria diperoleh saat proses wawancara dengan pihak dealer.

Tahapan selanjutnya adalah melakukan pengolahan data menggunakan Fuzzy AHP. Adapun tahapannya sebagai berikut:

a. Merata-ratakan hasil dari masing-masing kriteria untuk memperoleh bobot yang akan dibentuk ke dalam matriks perbandingan berpasangan.

b. Menyusun matriks untuk masing-masing kelompok.

c. Menghitung nilai eigen maksimum dan menguji konsistensi.

d. Jika hasil uji konsistensi memenuhi $C R<0.100$, maka bobot diubah ke dalam skala triangular fuzzy number.

e. Apabila tidak terpenuhi $C R<$ 0.100, maka penilaian diulang dengan perbaikan perbandingan berpasangan.

f. Menghitung nilai fuzzy synthetic extent.

g. Mengambil nilai minimum dari perbandingan nilai fuzzy synthetic extent.

h. Menormalisasikan vector bobot untuk memperoleh kriteria prioritas.

\section{HASIL PENELITIAN DAN PEMBAHASAN}

Berdasarkan hasil wawancara dan survey lapangan, maka diperoleh struktur hirarki kriteria mobil keluarga seperti pada Gambar 1.

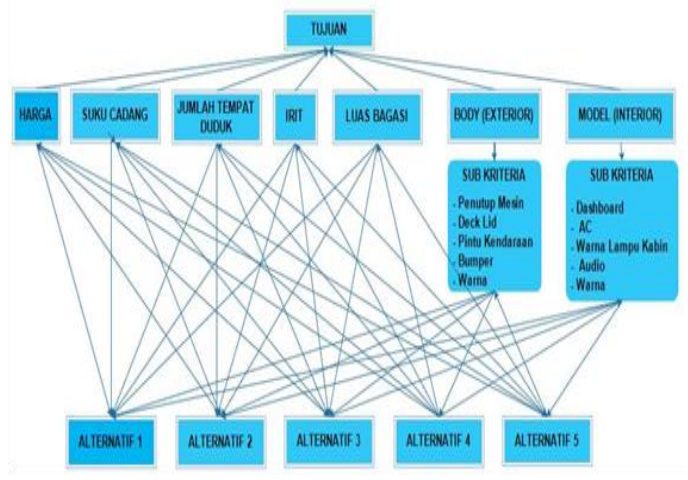

Gambar 1. Hirarki Kriteria Mobil

Keluarga

Selanjutnya melakukan pengolahan data menggunakan Fuzzy AHP untuk setiap kriteria. 
Berdasarkan permasalahan mengenai pemilihan mobil keluarga dibuatkan suatu program sebagai alternatif pengambilan keputusan yang cepat sesuai nilai bobot penilaian untuk menentukan pembelian mobil keluarga.

\section{Subsistem Antarmuka Pengguna}

\section{Halaman Awal}

Halaman awal merupakan tampilan yang pertama kali muncul pada saat aplikasipenilaian pemilihan mobil keluarga dijalankan. Pada sistem ini terdapat beberapa halaman antarmuka antara lain sebagai berikut :

Menu home merupakan tampilan awal aplikasi yang memberikan informasi penentuan kriteria pemilihan mobil keluarga mengenai petunjuk pengisian peniliain kriteria dengan member penilaian menurut individu (perorangan) dari yang paling penting ke yang paling tidak penting untuk pembelian kriteria mobil keluarga, yang paling penting diberi nilai yang paling tinggi dan yang tidak penting diberi nilai yang paling rendah. Skala nilai dari (1,2,3,4,5,6 atau 7) dengan memberi angka pada kolom, untuk setiap kriteria. Menu home dapat dilihat pada Gambar 2. Pada menu home terdapat tombol "Menu Penilaian" dan tombol "Keluar".

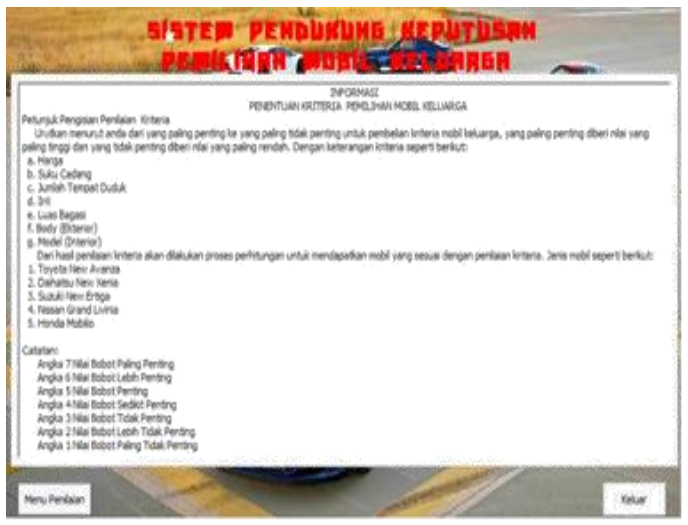

Gambar 2. Menu Home

\section{Halaman Kedua}

Halaman kedua merupakan tampilan penilaian kriteria untuk menentukan nilai kriteria mobil yang ditentukan sesuai petunjuk pengisian penilaian kriteria yang ada pada halaman awal.

Menu penilaian berfungsi untuk memberikan kecenderungan penilaian kriteria untuk penentuan nilai kriteria mobil. Menu penilaian akan melakukan proses perhitungan sesuai dengan nilai kriteria yang diberikan dan rekomendasi hasil dari penilaian akan mendapatkan mobil yang cocok untuk kriteria mobil keluarga. Menu penilaian dapat dilihat pada Gambar 3. Pada menu penilaian terdapat tombol "Proses" dan tombol "Keluar". 


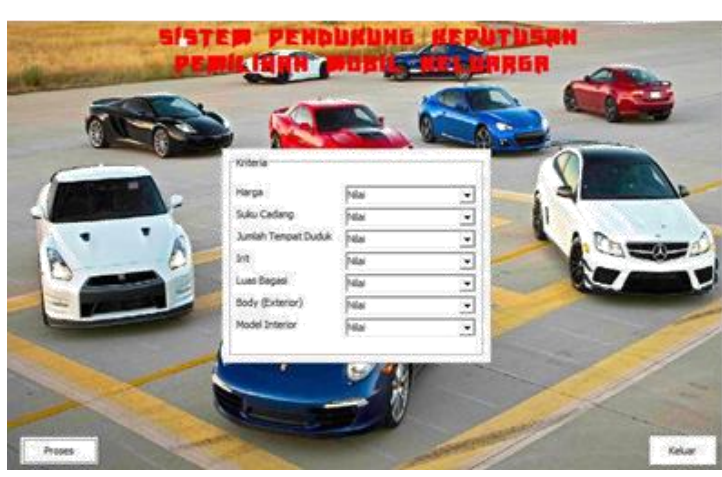

Gambar 3. Menu Penilaian

\section{KESIMPULAN DAN SARAN}

\section{Kesimpulan}

Pada penelitian ini telah berhasil dilakukan penerapan metode Fuzzy AnalyticHierarchy Process (F-AHP) dalam menentukan pembelian mobil keluarga, dengankriteria-kriterianya adalah, harga, suku cadang, jumlah tempat duduk, irit, luas bagasi, body (eksterior) dan model (interior). Berdasarakan hasil survey dan kemudian dilakukan perhitungan menggunakan metode Fuzzy Analytic Hierarchy Process (F-AHP) diperoleh nilai bobot masing-masing kriteria secara berurutan harga dengan nilai bobot $28.59 \%$, suku cadang dengan nilai bobot $10.388 \%$, jumlah tempat duduk dengan nilai bobot $22.862 \%$, irit dengan nilai bobot $29.144 \%$, luas bagasi dengan nilai bobot $1.734 \%$, body (eksterior) dengan nilai bobot $5.546 \%$ dan model (interior) dengan nilai bobot $1.734 \%$. Melihat hasil ini disimpulkan bahwa kecenderungan masyarakat gorontalo dalam memilih kendaraan keluarga lebih mementingkan harga sebesar $28.59 \%$ dan irit sebesar $29.144 \%$.

Pada Penelitian ini juga telah dibuat, suatu aplikasi yang dapat membantu dan memudahkan pembeli dalam menentukan pembelian mobil keluarga, dengan inputan adalah kriteria - kriteria sebagai berikut, harga , suku cadang, jumlah tempat duduk, irit, luas bagasi, body (eksterior) dan model (interior) yang dapat diisi lansung konsumen dan outputnya adalah rekomendasi kendaraan yang cocok untuk kriteria yang diinginkan konsumen.

\section{Saran}

Penelitian ini hanya difokuskan pada pemilihan mobil keluarga yang ada di Kota Gorontalo. Untuk itu diharapkan pada pengembangan sistem pendukung keputusan selanjutnya, perlu penambahan fitur-fitur body (eksterior) dan model (interior) yang menentukan kriteria agar hasil yang diperoleh lebih detail dan mampu memenuhi keinginan konsumen yang ada di Provisi Gorontalo. 


\section{DAFTAR PUSTAKA}

[1] Adnyana,T.G.A.F., Nilakusmawati, D.P.E., 2016. Penerapan Metode Fuzzy AHP

[2] Dalam Penentuan Sektor Yang Berpengaruh Terhadap Perekonomian Provinsi Bali. EJurnal Matematika. Universitas Udayana.

[3] Artika, R, 2013. Penerapan Analitycal Hierarchy Procces $(A H P) \quad$ Dalam PendukungKeputusan Penilaian Kinerja Guru Pada SD Negeri 095224. Jurnal. Pelita

[4] Galu, M.E.P., 2015. Analisa penggunaan Metode AHP Dan Fuzzy AHP Pada Perangkingan Siswa. Jurnal. Universitas Maritim Raja Ali Haji (UMRAH).

[5] Susanto, A, I.S., 2014. Penggunaan Metode Analytic Hierarchy Process (AHP) Untuk Seleksi Guru Tetap Yayasan Adhi Luhur. Jurnal. Universitas Indraprasta PGRI.

[6] Wahyuni, S, Hartati,S. 2012. Sistem Pendukung Keputusan Model Fuzzy AHP Dalam Pemilihan Kualitas Perdagangan Batu Mulia. Jurnal. FMIPA UGM,Yogyakarta. 